\title{
Samopomoc jako alternatywny sposób zapewnienia efektywnej ochrony praw prywatnych w prawie rzymskim
}

U zarania dziejów państwowości rzymskiej, w okresie charakteryzującym się jeszcze słabością władzy państwowej, problem konfliktu pomiędzy drogą procesową a rozstrzyganiem sporów w drodze samopomocy nie mógł w ogóle powstać. Władza nie posiadając wówczas wystarczająco sprawnego aparatu przymusu pozostawiła, bardziej z konieczności, niż z wyboru, rozwiązywanie sporów samej społeczności w jej własnym zakresie wedle utrwalonych zwyczajem reguł. Tymczasem od narodzin prawa i procesu rzymskiego, a w formie pisanej na pewno od chwili uchwalenia Ustawy XII Tablic, samopomoc może być już postrzegana jako zaledwie alternatywa rozwiązywania konfliktów prawnych wobec coraz częściej narzucanej przez porządek prawno-państwowy właściwej drogi sądowej. ${ }^{1}$ Słuszny jest jednak pogląd, że zachowane brzmienie pierwszych trzech tablic zrekonstruowanej Ustawy XII Tablic nie daje raczej podstaw aby sądzić, że państwo miało jakiś szczególny program ukrócenia powszechnie stosowanej wcześniej samopomocy. ${ }^{2}$ Przyglądając się całościowo dziejom prawa rzymskiego będzie można zauważyć wszakże klarowny kierunek przemian od czasów, gdy prawo i sądownictwo państwowe stawiało swe pierw-

\footnotetext{
* Prof. dR hab. Krzysztof AmielańCzy - Katedra Prawa Rzymskiego UMCS w Lublinie; amielan@interia.pl.

${ }^{1} \mathrm{Na}$ temat mechanizmu zastępowania samopomocy w rozstrzyganiu sporów pomocą państwa L. Wenger, Institutes of Roman Law of Civil Procedure, New York 1955, s. 8-19.

2 Przekonują o tym nieliczne dostępne formy legis actiones, ograniczenia dostępu do procesu legisakcyjnego z uwagi na wysokie kwoty sacramentum, które czyniły prowadzenie postępowań sądowych raczej rzadkim zjawiskiem ograniczonym do poważnych przypadków i dotyczących konfliktów miedzy bogatymi obywatelami, zob. W. Dajczak, T. Giaro, F. Longchamps de Beriér, Prawo rzymskie. U podstaw prawa prywatnego, Warszawa 2014 (2 wyd.), s. 147-148.
} 
sze kroki w okresie archaicznym do czasów, gdy rozwinął się i okrzepł rzymski system wymiaru sprawiedliwości w okresie klasycznym i poklasycznym. Ten kierunek polegał na postępującej reglamentacji uprawnień do podejmowania aktów samopomocy przy jednoczesnej akceptacji, co do zasady, naturalnie przysługującego każdemu człowiekowi prawa do tego, aby przed zastosowaną bezprawną przemocą mógł bronić się z użyciem siły. ${ }^{3}$ Choć prawo do podjęcia działań w ramach samopomocy najbardziej wyraziście konkretyzowało się w ramach tzw. obrony koniecznej, kontratypu rozważanego na gruncie prawa karnego publicznego, w prawie rzymskim prywatnym miało także szczególnie silne konotacje. ${ }^{4}$ Dość powiedzieć, że już Ustawa XII Tablic ${ }^{5}$, najwcześniejszy pisany akt prawny Rzymian, sformułowała reżim podjęcia działań w ramach samopomocy w przypadku usiłowania furtum, będącego w czasach wczesnej republiki deliktem o bardziej publicznym, niż prywatnym charakterze. W ten sposób samopomoc stać się miała, po pierwsze, dozwoloną, choć często drastyczną alternatywą zakończenia konfliktu, wobec kłopotliwego procesu prywatnego o zwrot skradzionej rzeczy. Po drugie, w przypadku odzyskania rzeczy, także na skutek zakończonej w domu podejrzanego o kradzież rewizji lance et licio, stanowić mogła dobre przygotowanie do procesu o grzywnę (na podstawie actio furti manifesti).

Trzymając się chronologii dziejów prawa rzymskiego, także lex Aquilia dostarczyła przykładów dopuszczalności samopomocy, którym prawo gwarantowało bezkarność. Znacząca aktywność naukowa jurystów dotycząca tej ustawy potwierdzona obszernym tytułem Digestów justyniańskich ${ }^{6}$ obejmuje zarówno rozstrzygnięcia kazuistyczne, jak i zawiera sformułowane przez Paulusa uogólnienie: vim vi defendere omnes leges omniaque iura permittunt.

Wreszcie samopomoc, rozważana na gruncie prywatnoprawnego sporu posesoryjnego, dała okazję Ulpianowi do powtórzenia za Kasjuszem słynnej i znanej dziś powszechnie zasady vim vi repellere licet. I choć to właśnie nadużywana zbyt często samopomoc była głównym powodem wprowadzenia rozbudowanej ochrony posesoryjnej przez magistratury pretorskie, to paradoksalnie, przy okazji, edykt pretorski utrwalił i zagwarantował prawo do ochrony posiadania

${ }^{3}$ Według L. Wengera, Institutes..., s. 8, samopomoc, w dłuższej perspektywie, skazana była na przegraną w konfrontacji z modelem rozstrzygania sporów na drodze procesu z dwóch zasadniczych powodów: nikt nie powinien być sędzią we własnej sprawie (nemo iudex in causa sua), a ponadto słabszy zawsze przegrałby rywalizację z silniejszym pomimo posiadanych racji.

${ }^{4}$ Podobnie jak we współczesnym prawie polskim, zob. art. $25 \$ 1$ k.k. Nie popetnia przestępstwa, kto w obronie koniecznej odpiera bezpośredni, bezprawny zamach na jakiekolwiek dobro chronione prawem; Art.423 k.c. Kto działa w obronie koniecznej, odpierając bezpośredni i bezprawny zamach na jakiekolwiek dobro własne lub innej osoby, ten nie jest odpowiedzialny za szkode wyrzadzonq napastnikowi.

${ }^{5}$ Polską rekonstrukcję przepisów Ustawy XII Tablic zawiera opracowanie M. i J. Zabłockich, Ustawa XII Tablic. Tekst - tłumaczenie - objaśnienia, Warszawa 2000.

${ }^{6}$ Zob. zwłaszcza tytuł D. 9,2,0 Ad legem Aquiliam. 
uzyskanego na drodze samopomocy, skoro posiadanie chronił tak dalece, że nawet posiadacz wadliwy, a więc taki który przecież odebrał komuś posiadanie siłą - vim, mógł liczyć na interwencję państwa, jeśli następnie bronił się przed napastnikiem władającym bronią przed wyzuciem go z tak uzyskanego władztwa.

Zwykło się w literaturze wyróżniać samopomoc dozwoloną i niedozwoloną. ${ }^{7}$ Nie kwestionując logiki i prostoty tego podziału, należałoby jednak zauważyć jego niską przydatność do rozważań teoretyczno-prawnych. Podział bowiem ściśle oddaje jedynie historyczną zmienność (koniunkturalność) zjawiska. To od stanowiska władzy państwowej w wybranym do analizy momencie historii, jej aktywności, bądź bierności w zakresie angażowania się w spory między członkami danej społeczności zależała każdorazowo kwalifikacja danego „samopomocowego" zachowania jako dozwolonego, bądź nie. ${ }^{8}$ Przy czym takim arbitralnym postawom władzy publicznej w czasach rzymskich rzadko towarzyszyło głośno artykułowane uzasadnienie. Dużo ciekawszy podział, inspirujący do naukowych dywagacji, przebiega w innej płaszczyźnie. Otóż samopomoc można podzielić na działania zaczepne, inicjujące zmianę stanu faktycznego (samopomoc aktywną) i działania obronne (samopomoc pasywną), polegające na przeciwdziałaniu próbom zmiany stanu faktycznego przez inną osobę. ${ }^{9}$ Samopomoc aktywną postrzegać można w dwóch wymiarach: jako działania zastępujące (wyręczające) postępowanie sądowe i jako działania wspierające, towarzyszące, czy też nawet warunkujące wszczęcie postępowania sądowego. ${ }^{10}$ Ograniczenia samopomocy przez prawodawcę będą pojawiały się w dalszej perspektywie historycznej zwłaszcza w tym pierwszym wymiarze - samopomocy aktywnej. Z kolei, w przypadku samopomocy pasywnej, mówić możemy o narodzinach konstrukcji obrony koniecznej, nazywanej tak dzisiaj zarówno w języku prawa prywatnego, jak i karnego. Ta ostatnia podlegać będzie w prawie rzymskim znacznie mniejszym ograniczeniom, niż samopomoc aktywna (zaczepna). W poszukiwaniu tradycji obrony koniecznej przydatne są te teksty źródłowe, które pozwalają zrekonstruować na poszczególnych etapach historycznego rozwoju prawa rzymskiego wymagania stawiane przez prawodawcę

Zob. chociażby W. Litewski, Rzymskie prawo prywatne, Warszawa 1999, s. 347-348. Por. także ostatnio K. Amielańczyk, Vis - pomiędzy prawem rzymskich deliktów prywatnych a rzymskim prawem karnym publicznym, w: Przemoc w świecie starożytnym. Źródła, struktury, interpretacje, Lublin 2017, s. $283-298$.

${ }^{8}$ Wystarczy wskazać w tym miejscu na dzieje ustawodawstwa de vi, a w szczególności ponadczasowe znaczenie lex Iulia de vi privata i lex Iulia de vi publica.

9 Tak W. Dajczak, T. Giaro, F. Longchamps de Berier, Prawo rzymskie..., s. 145. Niekiedy odróżnia się samopomoc od obrony koniecznej (zob. np. A. Dębiński, Rzymskie prawo prywatne. Kompendium, Warszawa 2011, s. 88.

${ }^{10}$ Liczne elementy samopomocy, jako swoiste relikty przeszłości, pojawiły się natomiast w procedurze legisakcyjnej. Wystarczy choćby wspomnieć o in ius vocatio czy egzekucji osobistej. Nie będą one przedmiotem rozważań w niniejszym opracowaniu. 
wobec działań obronnych podejmowanych przez zaatakowanego, tak by mógł on skorzystać z dobrodziejstwa bezkarności, jeśli w ten sposób naruszy dobra napastnika. ${ }^{11}$

Celem opracowania jest, po pierwsze, dokonanie przeglądu wybranych, udokumentowanych źródłowo, rzymskich regulacji prawnych przyzwalających na stosowanie samopomocy. Przykładów jej obecności dostarczają przede wszystkim Ustawa XII Tablic, wypowiedzi jurystów klasycznych formułowane na gruncie wykładni edyktu pretorskiego (dotyczące interdyktów posesoryjnych) oraz Ustawy Akwiliańskiej, a także konstytucje cesarskie. Po drugie, warto podjąć próbę zrozumienia stałej obecności instytucji samopomocy na różnych etapach rozwoju prawa rzymskiego w sytuacji gdy prawo rzymskie uchodzi przecież za wzór sądowej ochrony praw prywatnych, a "procesowy” charakter prawa rzymskiego nie podlega dyskusji.

Na temat samopomocy w prawie rzymskim zarówno w kontekście Ustawy XII Tablic, pretorskiej ochrony posesoryjnej, czy też lex Aquilia dostępna jest obszerna literatura. ${ }^{12}$ Dlatego uwagi na jej temat ograniczone zostaną do podstawowych źródeł i ukierunkowane zgodnie z tematem konferencji na kwestię efektywności ochrony praw prywatnych, bądź też jej braku, w prawie i procesie rzymskim.

\section{Samopomoc i kradzież zuchwała w Ustawie XII Tablic.}

Jak już wspomniano, tradycję samopomocy odnaleźć można nie tylko w rzymskim prawie karnym, ale także prywatnym. ${ }^{13}$ Nawiasem mówiąc, wyróżnianie w tym przypadku tzw. „rzymskiego prawa karnego”, zwłaszcza w dobie Ustawy XII Tablic, może być uznane za zabieg nieco sztuczny, gdyż prawo karne, ani wtedy ani później, nie tworzyło osobnego systemu. Nawet w czasach, gdy

${ }^{11}$ Zob. K. Amielańczyk, Czy kontratyp obrony koniecznej ma rzymską tradycję? W poszukiwaniu przesłanek dopuszczalności prawa do samoobrony w rzymskim prawie karnym, w: Quid leges sine moribus? Studia nad prawem rzymskim dedykowane Profesorowi Markowi Kuryłowiczowi w 65. Rocznicę urodzin oraz 40-lecie pracy naukowej (pod red. K. Amielańczyka), Lublin 2009, s.51-72.

${ }_{12} \mathrm{~W}$ polskiej romanistyce przegląd poglądów na konstrukcję i naturę samopomocy zawierał już artykuł M. Staszków, Teoria o „Selbsthilfe” i jej „nowocześni” krytycy, „ZN UWr” 27 Prawo 7 (1960), 201-216.

13 Słusznie dlatego w literaturze przy poszukiwaniu genezy obrony koniecznej czynione są odniesienia zarówno do prawa karnego (publicznego), jak i prywatnego, zob. w szczególności: T. Mayer-Maly, Vis, „Paulys Realencyclopädie“ IX A (1961), s. 315-327 (zwłaszcza rozdział: „Vis als Selbshilfe”), M. Bohácek, Si se telo defendit, w: Studi in onore V. Arangio-Ruiz, I, Napoli 1953, s. 147-172., G. Luzzato, Von der Selbsthilfe zum römischen Prozeß, „Zeitschrift der Savigny - Stiftung für Rechtsgeschichte. Romanistische Abteilung" 73 (1956), s. 27-67. Podstawowe informacje wraz z literaturą zamieszcza także M. Kaser, Das Römische Privatrecht, II, München 1975, s. 64 przyp. 6-8. 
rozwinęła się rzymska jurysprudencja klasyczna juryści nie widzieli potrzeby wyodrębnienia takiej gałęzi prawa z rzymskiego ius ${ }^{14}$.

Tradycja instytucji samopomocy w prawie decemwirów związana jest z uprawnieniem do zabicia w obronie własnej złodzieja usiłującego dokonać kradzieży zuchwałej, w dwóch określonych sytuacjach:

\begin{abstract}
Lex duodecim tabularum 8,12-13. Si nox furtum faxit, si im occissit, iure caesus esto. Luci..., si se telo defendit,... endoque plorato. ${ }^{15}$

D.9,2,4,1 (Gaius libro septimo ad edictum provinciale): Lex duodecim tabularum furem noctu deprehensum occidere permittit, ut tamen id ipsum cum clamore testificetur: interdiu autem deprehensum ita permittit occidere, si is se telo defendat, ut tamen aeque cum clamore testificetur.
\end{abstract}

Według zrekonstruowanego przepisu Ustawy XII tablic i komentarza Gaiusa można było zabić złodzieja przyłapanego pod osłoną nocy, o ile napadnięty podniósł uprzednio krzyk. Złodzieja przyłapanego za dnia Ustawa pozwalała zabić w sytuacji, gdy pomimo podniesionego przez napadniętego krzyku, napastnik sięgnął po broń. ${ }^{16}$

Wymóg podniesienia przez poszkodowanego krzyku (clamor) warunkującego prawo do zabicia złodzieja nocnego (fur nocturnus) jest w nauce rozmaicie interpretowany, nie można wykluczyć, iż miał także charakter ostrzeżenia, że napadnięty czuje się zagrożony i może użyć siły w celu odparcia zamachu ${ }^{17}$.

W przypadku, gdy złodziej zakradł się za dnia, mógł zostać zabity jedynie wtedy, gdy sięgnął po broń aby przełamać obronę podjętą przez napadniętego. Jeśli działał w nocy, uzasadnieniem dla dopuszczalności zabicia intruza były niejasne jego zamiary, które zazwyczaj trudno było zidentyfikować, skoro działał

${ }^{14}$ Nie stworzyli zatem systemu ius poenale, czy ius criminale, por.: L. Garofalo, Pojęcia i żywotność rzymskiego prawa karnego, „Zeszyty Prawnicze UKSW“ 3.1 (2003), s. 17. Podobnie: M. Kuryłowicz, Ustawodawstwo rzymskie w sprawach karnych, „Annales UMCS” 35.1 (1988), s. 29-30, A. Wiliński, Das römische Recht. Geschichte und Grundbegriff des Privatrechts mit einem Anhang über Strafrecht, Leipzig 1966, s.89.

15 Tłum.: „Jeśli nocą kradł, gdy (okradany) go zabił, niech będzie (traktowany jako) zabity zgodnie z prawem. W dzień...jeśli się bronił orężem,...niech (okradany) podniesie krzyk.” (Za rekonstrukcją: M. i J. Zabłoccy, Ustawa XII Tablic., s. 55-57.

${ }_{16}$ Termin telum oznacza tu broń ofensywną, służącą do atakowania, w przeciwieństwie do znanego również Rzymianom terminu arma, który raczej oznaczał broń defensywną. Rozróżnienie telum i arma przewidywały przepisy legis Iuliae de vi publica.

${ }_{17}$ M. i J. Zabłoccy, Ustawa XII Tablic, s. 56 (uwaga 14), zasadnie, krzyk okradanego interpretują jako „podkreślenie bezprawności działania sprawcy”. Edward Gintowt upatrywał w podniesieniu krzyku celu jakim miało być zalecane przez Ustawę XII Tablic przywołanie świadków bezprawnej, dokonanej przy użyciu broni, por.: E. Gintowt, Rzymskie prawo prywatne w epoce postępowania legisakcyjnego, Warszawa 2005, s. 105-106. Słowa ustawy endo plorare miałyby znaczyć to samo co clamore testificare, op.cit., s.105 przyp. 25, por. także: F. Wieacker, Endoplorare. Diebstahlsverfolgung und Gerüft in altrömischen Recht, w: Festschrift für L. Wenger I, München 1944, s. 129-179. 
pod osłoną mroku. Zazwyczaj zaskoczony podczas snu domownik, nie miał przecież możliwości prawidłowej oceny zamiarów złodzieja: czy dotyczą one pozbawienia go życia, czy tylko kradzieży mienia, a może naruszenia obu tych dóbr równocześnie? Tu więc podniesienie krzyku było ze wszech miar wskazane: przepłoszyłoby pospolitego rabusia i okazało się wystarczającym sposobem obrony. Brak ze strony napastnika reakcji uznawano zapewne za deklaracje poważniejszych zbrodniczych zamiarów wymierzonych przeciwko życiu ofiary $i$ to zdaniem ustawodawcy stanowiło przyzwolenie na zabicie intruza.

Sytuacja, gdy sprawca działający w dzień nie posiadał broni jest jeszcze bardziej czytelna. Takiego złodzieja, który nieuzbrojony zakradł się za dnia, łatwiej było zidentyfikować jako szukającego jedynie materialnego łupu. Ustawa nie pozwalała go więc zabić, tak długo jak długo nie wyciągnął broni przeciwko ofierze próbującej go przepędzić. Uprawnienie do zabicia napastnika działającego w dzień, uwarunkowane przypuszczeniem przezeń ataku bronią, każe upatrywać w obu łącznie interpretowanych przepisach ochrony także życia (zdrowia) napadniętej ofiary, nie zaś aktu wymierzenia napastnikowi w ten sposób kary za popełnione przestępstwo. Przepisy Ustawy są bardziej podyktowane troską o zapewnienie obywatelom prawa do samoobrony przed bezprawnym zamachem na ich prywatne dobra. ${ }^{18}$

Na temat przepisów dotyczących samoobrony w Ustawie XII Tablic, oprócz cytowanego wyżej Gaiusa, zabierali głos także Paulus i Ulpian ${ }^{19}$. Ich wypowiedzi dowodzą wykorzystywania przepisów Ustawy w argumentacji na temat wyłączenia odpowiedzialności karnej za zabicie napastnika grożącej na podstawie lex Cornelia de sicariis et veneficis (ustawy przeciwko zabójstwu). Mogą one jednak także pomóc w zrozumieniu uzasadnienia dla regulacji dopuszczającej samopomoc w prawie rzymskim:

\section{D.48,8,9 (Ulpianus libro septimo de officio proconsulis): Furem nocturnum si quis occiderit, ita} demum impune feret, si parcere ei sine periculo suo non potuit.

${ }^{18}$ G. Diósdi, Vim vi repellere licet. A contribution to the study of the question of self-defence in Roman Law, “Acta Universitatis Wratislaviensis. Antiquitas", I (1963), s. 190. W nauce później trwała dyskusja, czy przepisy Ustawy XII tablic przedstawiały konstrukcję obrony koniecznej (G. Longo), czy raczej prymitywne prawo do rewanżu przynależne właścicielowi (M. Kaser), por. W. Waldstein, rec. G. Longo, Sulla legittima difesa e sullo stato di necessità in diritto romano, w: Sein und Werden im Recht. Festgabe für U. von Lübtow, Berlin 1970), „Zeitschrift der Savigny - Stiftung für Rechtsgeschichte. Romanistische Abteilung" 89 (1972), s. 476 przyp.22. Oczywiście, pierwotnie prawo do zabicia napastnika mogło czerpać i takie uzasadnienie z tradycji, że złodziej działający w sposób opisany w Ustawie XII Tablic mógł być postrzegany jako homo sacer, tak zwłaszcza M. Bohácek, Si se telo defendit, s.150. Por. także G. Luzzato, Von der Selbsthilfe..., s.53.

19 Por. jeszcze wypowiedź na temat tradycji obrony koniecznej w Ustawie XII Tablic Cycerona: (Cic. pro Milone 3,9). Będzie o niej jeszcze mowa w dalszej części artykułu. 
Coll.7,2,1 (Paulus libro sententiarum V ad legem Corneliam de sicariis et veneficis) ${ }^{20}$ : Si quis furem nocturnum vel diurnum cum se telo defenderet occiderit, hac quidem lege non tenetur, sed melius fecerit, qui eum comprehensum transmittendum ad praesidem magistratibus optulerit.

Według Ulpiana, ten kto złodzieja nocnego zabija, tylko wtedy nie powinien ponieść kary, jeśli nie mógłby bez ryzyka dla siebie oszczędzić napastnika. Uprawnienie do zabicia złodzieja uzasadnione zostało przez jurystę obawą ofiary o własne życie ${ }^{21}$. Majątek prywatny poszkodowanego nie był zatem jedynym dobrem chronionym przez prawo do obrony własnej. Można chyba zaryzykować twierdzenie, że ochrona bezpieczeństwa napadniętego, rozumiana jako ochrona łącznie: jego życia i zdrowia była nawet ważniejszą ratio dla przepisów karnych ustawy XII Tablic dotyczacych kradzieży zuchwałej22.

Dla prowadzonych tu rozważań uwaga Ulpiana ma istotne znaczenie. Zbliża nas bowiem do zrozumienia dlaczego prawo dopuszczało samopomoc. Obrona wchodziła w grę tylko wtedy, gdy napadnięty nie miał innego, pozbawionego jakiegokolwiek dla niego ryzyka, sposobu uniknięcia grożącego niebezpieczeństwa naruszenia praw prywatnych. W szczególności nie miał ani czasu, ani możliwości, dochodzenia swych racji przed sądem.

W podobnym kierunku podążało także rozumowanie Paulusa, dotyczące wyboru sposobu działania przez napadniętego, które to rozumowanie może dostarczyć nieco materiału przydatnego dla prowadzonych tu rozważań. Paulus twierdził, że wprawdzie odpowiedzialność za zabójstwo na postawie lex Cornelia de sicariis et veneficis napadniętemu, który skorzystał z prawa do obrony własnej nie grozi, jednak lepiej czynił ten kto wybierał rozwiązanie polegające na pojmaniu złodzieja i dostarczeniu go do namiestnika.

Paulus, odmiennie niż Ulpian, akurat nie wspomniał nic o ryzyku związanym z takim wyborem, ale domyślać się trzeba, że zawsze takie ryzyko dla napadniętego istniało. Nie dziwi więc bezkarność osoby, która z takiej możliwości nie próbowała skorzystać i napastnika zdecydowała się jednak zabić. Obronę taką można by nazwać, wzorując się na współczesnej nomenklaturze, „obroną konieczną" 23.

$20=$ P.S.5,23,29. Por. jeszcze Coll.7,3,2 i 3.

21 Tak G. Diósdi, Vim vi repellere licet..., s.192.

22 J.M. Kelly, Roman Litigation, Oxford 1966, s. 161, słusznie podejrzewał, że pierwotnie przepisy Ustawy XII Tablic wymierzone były nie tyle w działających w pojedynkę złodziei, ile w groźnych bandytów, których działania charakteryzowały się szczególną zuchwałością, a napaści dopuszczano się częstokroć w kilka osób i zazwyczaj pod osłoną nocy.

${ }^{23}$ Na przesłankę konieczności zwracał szczególną uwagę w swej pracy G. Longo, Sulla legittima difesa, s. 331-337. Na okoliczność, że Rzymianie wymagali, by obrona konieczna realizowana była przy użyciu minimum siły wskazała O. Robinson, The Criminal Law of Ancient Rome, Baltimore 1996, s. 20. 
Prawo do zabicia złodzieja działającego pod osłoną nocy, jak też tego który zakradł się w dzień i użył broni było najstarszą, znaną prawu rzymskiemu regulacją dotyczącą obrony własnej ${ }^{24}$. Na pewno już samemu przywiązaniu Rzymian do swej tradycji prawnej przypisywać można, że w czasach działalności jurystów klasycznych (II-III w. n.e.) regulacja ta cieszyła się nadal popularnością i była wciąż żywo dyskutowana. Komentarze dotyczące ustawy autorstwa jurystów klasycznych nadal oddawały ducha prawa rzymskiego tej odległej epoki, skoro potwierdzały nawet dość osobliwe i kazuistyczne rozwiązanie polegające na uwarunkowaniu prawa do obrony - tej realizowanej w najbardziej radykalny sposób polegający na zabiciu napastnika - od takich przesłanek jak: podniesienie krzyku przez napadniętego (jeśli do zdarzenia doszło w nocy) i posługiwanie się bronią przez napastnika (jeśli do zdarzenia doszło w dzień). Juryści postulowali bowiem, by bezkarne pozostawało tylko takie działanie, które podjęto w sytuacji, że niemożliwa była żadna inna reakcja oszczędzająca złodzieja. ${ }^{25}$

Wiadomym przejawem dopuszczalności samopomocy w przypadku dokonania kradzieży była także procedura lance et licio obecna w Ustawie XII Tablic. ${ }^{26}$ Ustawa przyzwalała na przeprowadzenie w domu podejrzanego o kradzież swoistej rewizji w celu odnalezienia skradzionej i ukrytej rzeczy. Przeszukaniu towarzyszyć powinno spełnienie pewnych wymogów: poszkodowany winien być obwiązany w biodrach przepaską (licium), która stanowiła jedyne jego ubranie, a w dłoniach trzymać misę (lanx), wszystko to po to, aby uniknąć podejrzenia, że mógłby rzecz rewidowanemu podrzucić. Jeśli poszkodowany swą rzecz podczas rewizji odnalazł, sprawcę uważano za fur manifestus, złodzieja jawnego złapanego na gorącym uczynku. Wytaczając mu następnie proces na podstawie actio furti mógł liczyć poszkodowany na zasądzenie kary prywatnej in quadruplum w wysokości poczwórnej wartości skradzionej rzeczy.

Należy dla porządku przypomnieć, że kradzież zuchwała, inaczej jawna (furtum manifestum) stanowiła w dobie uchwalenia Ustawy XII Tablic bardziej przestępstwo publiczne niż delikt prywatny. Karana była pierwotnie chłostą i popadnięciem w zależność (może w niewolę) u poszkodowanego, a karą śmierci

${ }^{24}$ Por. także C. Gioffredi, I principi del diritto penale Romano, Torino 1970, s.91-93, G. Diósdi, Vim vi repellere licet..., s.188 (z dalszą literaturą). Na zaskakująco „dobre uregulowanie konstrukcji obrony koniecznej" w rzymskim prawie karnym wskazywał W. Litewski, Podstawowe wartości prawa rzymskiego, Kraków 2001, s. 168.

${ }^{25}$ Takie podejście do obrony koniecznej reprezentuje także współczesne prawo karne. W ramach obrony koniecznej można poświęcić dobro napastnika o wartości wyższej niż bronione, jednak konieczność obrony rozumieć należy jako wymóg podjęcia sposobu obrony prowadzącego do możliwie najmniejszej szkody, por. M. Mozgawa, (red.), Prawo karne materialne. Część ogólna, Warszawa 2011, s. 222 (z cytowanym orzecznictwem Sądu Najwyższego).

${ }^{26}$ Zob. zwłaszcza artykuły M. Zabłockiej, Quaestio cum lance et licio, w: Contra leges et bonos mores. Przestępstwa obyczajowe w starożytnej Grecji i Rzymie (pod red. H. Kowalskiego i M. Kuryłowicza), Lublin 2005, s. 379-388 oraz Quaestio cum lance et licio, „IURA” 54 (2003), s. 109-121. 
w przypadku niewolników ${ }^{27}$. Jednak na skutek aktywności pretorskiej furtum manifestum zmieniło swój charakter na prywatnoprawny, gdyż karę publiczną zastąpiła prywatna grzywna płacona poszkodowanemu w wysokości czterokrotnej wartości rzeczy. ${ }^{28}$ Można więc zadać podstawowe pytanie, dlaczego w sytuacji, gdy prawo rzymskie wycofało się z surowej represji publicznoprawnej wobec kradzieży zuchwałej na rzecz grzywny prywatnoprawnej, utrzymano jednocześnie przepisy umożliwiające zabicie fur nocturnus i fur diurnus (si is se telo defendat)?

Wprowadzenie do Ustawy, ale i utrzymanie w późniejszych wiekach przyzwolenia na zabicie złodzieja nocnego, jak i złodzieja działającego w dzień $\mathrm{z}$ bronią $\mathrm{w}$ ręku, upatrywać można przede wszystkim $\mathrm{w}$ niedostatkach ochrony jaką mogłoby zapewnić państwo. Złodziej działający w nocy trudny był z racji ciemności do identyfikacji i ścigania. Złodziej działający w dzień, jeśli wyjął broń stawał się z kolei bezpośrednim zagrożeniem dla życia ofiary. Nakazywanie napadniętemu, by w każdej sytuacji władającego orężem pojmał i postawił przed sądem byłoby ze strony państwa nadmiernym i naiwnym oczekiwaniem, w rezultacie przepisem trudnym do wyegzekwowania. Ofiara często traciłaby życie zanim mogłaby temu obowiązkowi zadośćuczynić. W końcu brakiem odpowiednich sił aparatu sądowego, czy szerzej wymiaru sprawiedliwości, należy tłumaczyć tak charakterystyczne rozwiązanie jak oddanie uprawnień do przeprowadzenia śledztwa przez ofiarę, która lance et licio może przeprowadzić przeszukanie domu potencjalnego złodzieja. Pomijając inne zapewne jeszcze względy, u podstaw samopomocowych regulacji dotyczących furtum manifestum leżało w każdym razie zapewnienie efektywnej, czyli skutecznej ochrony praw prywatnych obywateli rzymskich.

\section{Samopomoc i ochrona posiadania w edykcie pretorskim.}

Tradycja samopomocy, zarówno tej aktywnej jak i pasywnej w postaci obrony koniecznej, kontynuowana była w prawie rzymskim przede wszystkim w zakresie problematyki ochrony posiadania.

Samopomoc, jak wyżej wspomniano, dopuszczano już w dobie Ustawy XII Tablic jako skuteczny sposób ochrony posiadania rzeczy przed kradzieżą zuchwałą. Oczywiście ratio tej ochrony nie była wówczas uniwersalna w tym znaczeniu, że Ustawa nie tyle chroniła władztwo faktyczne posiadaczy w każdej sytuacji przed jego utratą, ile chroniła właścicieli w ich domach przed

27 Ustawa XII Tablic 8,14. Zob.. w ogólności: W. Wołodkiewicz, M. Zabłocka, Prawo rzymskie. Instytucje, Warszawa 2005, s. 245-246.

${ }_{28} \mathrm{Na}$ temat grzywny in quadruplum z tytułu popełnionego furtum manifestum zob. J.M. Kelly, Roman Litigation, s. 161-163. 
zakradającymi się w ich granice złodziejami. Wraz z rozwojem koncepcji różnicującej władztwo prawne nad rzeczą od władztwa faktycznego, do którego zasadniczo przyczyniło się prawo pretorskie, pojawiła się potrzeba zbudowania reżimu ochrony posesoryjnej, odróżnianej od petytoryjnej. Ten nowy reżim wymagał jednak nowego usytuowania samopomocy na tle przyjętej procedury interdyktowej. Co do zasady, wprowadzenie pretorskiej ochrony interdyktowej może być postrzegane jako wypowiedzenie wojny przez państwo aktom samopomocy. ${ }^{29}$ Interdykty miały stać się swoistym remedium na zbyt częste i zbyt gwałtowne „wymierzanie sprawiedliwości” we własnym zakresie przez strony konfliktu, bez skierowania sporu na drogę postępowania sądowego. W tej nowej sytuacji czasami z ochrony mógł skorzystać nawet posiadacz wadliwy. ${ }^{30}$ $\mathrm{Z}$ drugiej jednak strony, samopomoc, jeśli zastosowana w odpowiedni sposób, w odpowiednich okolicznościach, mogła nie tylko uzupełniać i wspierać procedurę interdyktową, ale służyć jako podstawa pretorskich ustaleń co do wadliwości czyjegoś posiadania.

Dla zobrazowania problematyki samopomocy dopuszczalnej w przypadku naruszenia posiadania pierwszoplanowy wydaje się być przekaz Ulpiana, zwłaszcza że zawiera słynną, powszechnie dziś znaną, paremię vim vi repellere licet:

\section{D.43,16,1,27 (Ulpianus libro sexagensimo nono ad edictum): Vim vi repellere licere Cassius} scribit idque ius natura comparatur: apparet autem, inquit, ex eo arma armis repellere licere. ${ }^{31}$

Jurysta powołał się w swym komentarzu do edyktu na pogląd żyjącego w I wieku - Kasjusza, który uzasadnił słuszność reguły prawnej vim vi repellere licere („siłę można odeprzeć siłą”) przez porównanie prawa do samoobrony z regułami panującymi w naturze. Dlatego, jak twierdził Kasjusz, oczywistym jest, że atak przypuszczony $\mathrm{z}$ użyciem broni, można było odpierać w ten sam sposób - bronią. ${ }^{32}$ Uzasadnienie prawa do zastosowania pomocy własnej zostało tutaj, podobnie jak w przypadku prawa do zabicia złodzieja z Ustawy XII Tablic,

29 Słynna pretorska formuła vim fieri veto znana jest przede wszystkim z przekazów jurystów rzymskich, Ulpiana(D.43,17,1 pr.) oraz Gaiusa (G.4,151-3). Na temat formuły pretorskiej „zakazuję użycia siły" zob. przede wszystkim L. Labruna, Vim fieri veto. Alle radici di una ideologia, Napoli 1971, s. 89-142, G. Diósdi, Vim vi repellere licet..., s. 187-199.

${ }^{30}$ Jeśli posiadaczowi wadliwemu odebrano rzecz zbrojnie. Wówczas pretor stosował interdykt de vi armata nakazujący zwrot rzeczy. Można go było wnieść nawet po roku od chwili naruszenia posiadania. Zob. G. 4,155

${ }^{31} \mathrm{Na}$ temat pochodzenia (autorstwa) paremii vim vi repellere licet i jej znaczenia w rzymskim prawie karnym zob. K. Amielańczyk, Vim vi repellere licet. Kilka uwag na temat genezy prawa do obrony koniecznej w prawie rzymskim, „Palestra” 11-12 (2008), s. 109-119.

32 Jest zatem prawdopodobne, że to właśnie Kasjusz jako pierwszy zredagował regułę vim vi repellere licet $\mathrm{w}$ tej właśnie, znanej dzisiaj formie językowej i to jego, z braku innych źródeł, należy uznawać za jej autora. 
wywiedzione wprost z natury. Można się zastanawiać, skąd się wzięła ta zgodność przyzwolenia na samopomoc ze strony państwa?

Łatwo dostrzec, że w obu przypadkach chodzi w istocie o ochronę posiadania rzeczy i o uniemożliwienie jej zaboru. Z jakich powodów fakt zagrożenia uprawnień do władania rzeczą przez jednostkę był na tyle doniosły, czy w inny sposób szczególny, że powodował odstąpienie państwa od wymagania by poszkodowany dochodził swych praw wyłącznie na drodze sądowej?

Jak się zdaje, obrona władztwa nad rzeczami należała do najdawniejszych, przy tym wręcz naturalnych, przyrodzonych człowiekowi uprawnień. Takie przesłanie wywieść można także z przekazu jurysty Florentinusa pochodzącego z jego Instytucji:

\section{D.1,1,3 (Florentinus libro primo institutionum): Ut vim atque iniuriam propulsemus: nam iure hoc evenit, ut quod quisque ob tutelam corporis sui fecerit, iure fecisse existimetur, et cum inter nos cognationem quandam natura constituit, consequens est hominem homini insidiari nefas esse.}

Tekst powyższy został umieszczony pomiędzy wypowiedziami innych jurystów, głównie Ulpiana, poświęconymi problematyce ius gentium, i nie ma wątpliwości, że do tej właśnie problematyki jurysta nawiązywał. Florentinus mówił o prawie do odpierania (propulsare) nie tylko przemocy (vis), ale też szerzej - bezprawia (iniuria). W tym ostatnim przypadku nie chodziło oczywiście o zniewagę sensu stricto, lecz raczej o wszelkie działania bezprawne. ${ }^{33} \mathrm{Z}$ ius gentium wywodzić się bowiem miała zasada, ze wszystko to, co ktoś uczynił dla swej ochrony uznane być powinno za zgodnie z prawem. Jurysta uznał, że naturalne więzy krwi łączące rodzaj ludzki uzasadniają przekonanie, że podstępne prześladowanie jednego człowieka przez drugiego (insidiae) jest przekroczeniem prawa. Ciekawe jest to, że jurysta użył dla nazwania bezprawnych działań szerokiego w znaczeniu terminu insidiae, zamiast choćby vis, sugerując tym samym, że bezprawie uprawniające do samopomocy może mieć charakter zarówno gwałtownego ataku (zamachu), jak i podstępnej zasadzki. ${ }^{34}$

Uprawnienie do obrony przed naruszeniem posiadania zostało potwierdzone także konstytucją cesarzy Dioklecjana i Maksimianusa z 290 r. Przekaz został zamieszczony w pierwszym fragmencie rozpoczynającym tytuł Kodeksu Justyniańskiego traktujący o interdykcie unde $v i^{35}$ :

\section{C.8,4,1: Recte possidenti ad defendendam possessionem, quam sine vitio tenebat, inculpatae} tutelae moderatione illatam vim propulsare licet.

${ }_{33}$ Tłumaczenie iniuria jako „niegodziwość” jest jednak chyba zbyt nieostre i nie pasuje do ścisłego prawniczego języka Florentinusa, zob. Digesta Iustiniani. Digesta Justyniańskie. Tekst i przekład, pod red. T. Palmirskiego, Kraków 2013-2017, s. 159.

${ }^{34}$ J. Sondel, Słownik łacińsko-polski dla prawników i historyków, Kraków 1997, s. 499.

${ }^{35}$ C. $8,4,0$. 
Konstytucja cesarska przyznała uprawnienie posiadaczowi niewadliwemu tylko do umiarkowanego, adekwatnego (moderatione) odparcia aktu przemocy zmierzającego do pozbawienia go posiadania. To ważne zastrzeżenie, bo pokazuje, że prawodawca nie przyzwalał na odpieranie zamachu w dowolny sposób. Postulowany umiarkowany sposób zapewne nierzadko wykluczał np. zabicie napastnika, jeśli atak nie był wymierzony równocześnie w osobę posiadacza, tj. jego życie i zdrowie. Powinien być zatem współmierny do zagrożenia, jakim była zaledwie utrata posiadania. Tutela inculpata w tekście znaczy mniej więcej tyle co współczesna obrona konieczna, czy też obrona własna. ${ }^{36}$ Zwrot vim propulsare, znany już z wypowiedzi Florentinusa, oznacza tutaj także nic innego jak odpieranie zamachu siłą ${ }^{37}$.

\section{Samopomoc i wyrządzenie szkody na gruncie lex Aquilia}

Problematyka uprawnionej samopomocy pojawiła się także w rozważaniach jurystów rzymskich dotyczących lex Aquilia niejako na marginesie rozważań na temat odpowiedzialności za szkodę jaka powstawała w majątku właściciela, gdy ktoś zabił jego niewolnika. O skutkach zabicia cudzego niewolnika, w okolicznościach obrony własnej informował choćby Gaius:

D.9,2,4 pr. (Gaius libro septimo ad edictum provinciale): Itaque si servum tuum latronum insidiantem mihi occidero, secures ero: nam adversus periculum naturalis ratio permittit se defendere.

Gaius tłumaczył obrazowo: „Jeśli zabiję twojego niewolnika, który urządził w celach rabunkowych (bandycką) zasadzkę na mnie, nie będę odpowiadał: ponieważ racja wynikająca $\mathrm{z}$ natury pozwala bronić się przed niebezpieczeństwem". W sytuacji zatem, gdy cudzy niewolnik zaatakowałby kogoś, ten mógłby bez obawy o odpowiedzialność prywatnoprawną z tytułu deliktu damnum iniuria datum zabić niewolnika, a jego właściciel nie miałby roszczenia deliktowego. Marginalnie można dodać, że po przekazie tym jurysta przypomniał przepisy Ustawy XII Tablic dotyczące prawa do zabicia złodzieja zuchwałego, omówione już wcześniej (D.9,2,4,1), które przytoczone w charakterze analogii, miały wspomóc argumentację jurysty wyrażoną w zakresie odpowiedzialności za zabicie niewolnika na gruncie lex Aquilia.

${ }^{36}$ Zwrot tutelam corporis wystąpił także w przekazie Florentinusa D.1, 1, 3. Zob. jeszcze tutela proprii corporis, por. J. Sondel, op.cit., s. 962.

${ }^{37} \mathrm{~W}$ kwestii terminologii stosowanej w prawniczym języku łacińskim na określenie czynności polegającej na odpieraniu zamachu zob. ostatnio A. Tarwacka, Searching for the Roots. Vis vi depulsa in the Concept of Cicero, „Miscellanea historico-iuridica”, 11 (2012), s.77-88. 
Co do zasady, podobny w wymowie jest przekaz Paulusa:

D.9,2,45,4 (Paulus libro decimo ad Sabinum): Qui, cum aliter tueri se non possent, damni culpam dederint, innoxii sunt: vim enim vi defendere omnes leges omniaque iura permittunt. sed si defendendi mei causa lapidem in adversarium misero, sed non eum, sed praetereuntem percussero, tenebor lege Aquilia: illum enim solum qui vim infert ferire conceditur, et hoc, si tuendi dumtaxat, non etiam ulciscendi causa factum sit.

Jurysta kategorycznie stwierdził, że osoby, które wyrządzają szkodę, w sytuacji, w której nie miały innego sposobu obrony, jak ten prowadzący do szkody, powinny zostać uwolnione od odpowiedzialności. Następnie Paulus nieco patetycznie uzasadnił, że jego opinia bierze się stąd, że wszystkie ustawy i cały system prawa zezwalają na bronienie się przemocą przeciwko przemocy. Oczywiście, dużo w tym zdaniu przesady, jednak jeśli jego autor bardziej na myśli ducha prawa, czy choćby ducha wiekopomnej Ustawy XII Tablic, nigdy przecież nie uchylonej, to zdanie powyższe jest zrozumiałe i uprawnione.

Uzupełniająco jurysta wytłumaczył, że odmiennie należy ocenić na gruncie lex Aquilia sytuację, w której ktoś w celu samoobrony rzucił kamień w stronę atakującego, ale uderzył nie jego, lecz przechodzącego obok, bo wtedy poniesie odpowiedzialność z lex Aquilia. Dozwolone jest bowiem użycie przemocy jedynie wobec atakującego (stosującego przemoc) niewolnika, mało tego, tylko wtedy, gdy ta przemoc konieczna jest do samoobrony, a nie dla zemsty. ${ }^{38}$

\section{Samopomoc i konstytucje cesarskie}

Stosunek cesarstwa do stosowania samopomocy nie był jednolity. Jak już wspomniano na wstępie, kierunek ewolucji był co do zasady taki, że samopomoc ograniczano, zwłaszcza tę aktywną. Kwintesencją takiej postawy prawodawcy rzymskiego okazał się słynny dekret divi Marci cesarza Marka Aureliusza:

D.4,2,13 (Callistratus libro quinto de cognitionibus): Exstat enim decretum divi Marci in haec verba: "Optimum est, ut, si quas putas te habere petitiones, actionibus experiaris. Cum Marcianus diceret: vim nullam feci, Caesar dixit: Tu vim putas esse solum, si homines vulnerentur ? Vis est et tunc, quotiens quis id, quod deberi sibi putat, non per iudicem reposcit. Quisquis igitur probatus mihi fuerit rem ullam debitoris vel pecuniam debitam non ab ipso sibi sponte datam sine ullo iudice temere possidere vel accepisse, isque sibi ius in eam rem dixisse: ius crediti non habebit ".

38 Por. jeszcze Coll.7,3,2 i 3. 
Przytoczony przekaz Callistratusa znajdujący się w tytule Quod metus causa gestum erit Digestów justyniańskich $(\mathrm{D} .4,2,0)^{39}$ zawiera cytat pochodzący $\mathrm{z}$ dekretu cesarza dotyczący problemu rozumienia przemocy (vis). Cesarz sugeruje w nim, że najwłaściwszym dla zaspokojenia roszczeń jest posłużenie się skargami procesowymi. Nawet jeśli nie uży to przemocy fizycznej wywołującej obrażenia, ale ktoś domagał się czegoś bez udziału sędziego (nie wchodząc na drogę sądową) twierdząc że mu się coś należy, to wtedy zdaniem cesarza również do przemocy doszło. Cesarz konsekwentnie zapewnił, że zawsze wtedy gdy zostanie dowiedzione, że ktoś bez wyroku sądowego przypisując sobie samemu do tego prawo wszedłby w posiadanie lub przyjął rzecz bądź pieniądze należne od dłużnika, ale które nie zostały mu wydane z jego własnej woli, straci w ten sposób przysługujące mu prawa wierzyciela.

Tak więc dekret Marka Aureliusza oznaczał obowiązek sądowego dochodzenia wierzytelności, albo patrząc na sprawę z innej strony: bezwzględny zakaz stosowania samopomocy aktywnej w stosunkach zobowiązaniowych. ${ }^{40}$ Wierzyciele stosujący przemoc tracili swe wierzytelności jeśli pomijali drogę postępowania sądowego. Ta bezwzględność przejawiała się dodatkowo w szerokim pojmowaniu przemocy obejmującym nie tylko przemoc fizyczną (odebranie rzeczy), ale także psychiczną - groźbę, którą wymuszano określone zachowania od dłużnika. Zakaz uciekania się do samopomocy aktywnej przybrał ostatecznie postać uniwersalnej reguły prawnej, gdyż został zamieszczony w tytule $D e$ regulae iuris Digestów Justyniana:

D.50,17,176 pr. (Paulus libro 13 ad Plautium): Non est singulis concedendum, quod per magistratum publice possit fieri, ne occasio sit maioris tumultus faciendi.

Inne losy stały się udziałem samopomocy pasywnej, czyli obrony własnej, która nawet ulegała, jak się zdaje, okresowemu wzmocnieniu. W 391 r. została wydana przez współrządzących cesarzy: Walentyniana, Teodozjusza i Arkadiusza ważna konstytucja, pokazująca, że ówcześni rzymscy prawodawcy nadal stali na straży dopuszczalności stosowania obrony koniecznej, zwłaszcza stosowanej w przypadkach kradzieży zbrojnej:

CTh.9,14,2. Impp. Valent., Theodos. Et Arcad. A.A.A ad provinciales. Liberam resistendi cunctis tribuimus facultatem, ut quicumque militum vel privatorum ad agros nocturnus populator

39 Przekaz został powtórzony przez kompilatorów justyniańskich w D. 48,7,7 (w tytule Ad legem Iuliam de vi privata).

${ }^{40}$ Generalny zakaz zabierania rzeczy przemocą (tak fizyczną, jak psychiczną wywołującą bojaźń) wynikał także z edyktu pretorskiego, o czym informował Ulpian w rozpoczynającym tytuł Digestów przekazie D.4,2,1 (Ulpianus libro 11 ad edictum): Ait praetor: „Quod metus causa gestum erit, ratum non habebo". Olim ita edicebatur "quod vi metusve causa": vis enim fiebat mentio propter necessitatem impositam contrariam voluntati: metus instantis vel futuri periculi causa mentis trepidatio. Sed postea detracta est vis mentio ideo, quia quodcumque vi atroci fit, id metu quoque fieri videtur. Zob. jeszcze C. $3,39,4 ; 8,4,7 ; 8,4,10$. 
intraverit, aut itinera frequentata insidiis aggressionis obsederit, permissa cuicumque licentia, dignus illico supplicio subiugetur, ac mortem, quam minabatur excipiat, et id, quod intendebat, incurrat. Melius est enim occurrere in tempore, quam post exitum vindicari. Vestram igitur vobis permittimus ultionem, et, quod serum est punire iudicio, subiugamus edicto. Nullus parcat militi, cui obviari telo oporteat ut latroni. Dat. Cal. Iul. Tatiano et Symmacho Coss. ${ }^{41}$

Lektura tekstu nieodparcie rodzi skojarzenie z kategorią fur nocturnus znaną z Ustawy XII Tablic i obroną konieczną. Konstytucja została jednak ogłoszona w związku z rozprzestrzeniającą się plagą bandyckich napadów zorganizowanych grup przestępczych - latrones na poruszających się szlakami handlowymi podróżnych, jak też właścicieli posiadłości położonych wzdłuż dróg ${ }^{42}$. Przestępczość taka spowodowała nawet powołanie specjalnej kategorii urzędników sądowej policji śledczej przydzielanych namiestnikom, a zajmujących się jej ściganiem ${ }^{43}$. Rozporządzenie to poprzedzały być może liczne, ale prawdopodobnie nieskuteczne, konstytucje cesarskie sięgające ubiegłego wieku. ${ }^{44}$ Żołnierze zostali w edykcie zrównani z pospolitymi rabusiami z uwagi na częstą praktykę ich przenikania do band zbójeckich plądrujących okolice. ${ }^{45}$

Autorzy konstytucji tłumaczą przyznanie prawa do samoobrony niebezpieczeństwem utraty życia napadniętej osoby i niewielką „satysfakcją” płynącą z ukarania sprawcy, jeśliby wcześniej doszło do śmierci ofiary. W takich okolicznościach obrona rozumiana być powinna jako podjęta $\mathrm{w}$ stanie konieczności. Wskazują na to ostatnie słowa konstytucji, gdzie jej twórcy wręcz zalecają, aby napadnięty nie zawahał się zabić bandyty, który zastąpiłby mu drogę. Dostrzegają

$41=$ C.3,27,1pr

${ }^{42}$ Rozbójnicy (latrones) stali się ogromnym problemem społecznym już w 2 poł. II wieku n.e., a problem stał się zwłaszcza dotkliwy w wieku III n.e Por. zwłaszcza L. Lacché, Latrocinium, Milano 1988 (passim) oraz bogato udokumentowaną źródłowo pracę M.F.P. Lucernoni, Gli stationarii il Età Imperiale, Rome 2001 (passim). T. Łoposzko, Zarys dziejów społecznych cesarstwa rzymskiego, Lublin 1989, s. 196-197, uważał, że potrzeba zastopowania rozwoju latrocinium, które przybrało już za czasów Antoninów formę ruchu społecznego, stała się jedną z najbardziej dla cesarstwa palących.

43 Instytucja irenarchae dotyczyła zwłaszcza Azji, ale także Egiptu i terenów zamieszkałych przez narody greckojęzyczne. W pozostałych prowincjach urzędnicy tacy nazywali się stationarii. Podstawowe informacje podaje W. Litewski, Rzymski proces karny, Kraków 2003, s. 8-9, 74.

44 Zachowane zostały dwie takie konstytucje, cesarza Gordiana z 243 r.: C.9,16,2 Gord. Si, qui adgressorem vel quemcunque alium in dubio vitae discrimine constitutus occiderit, nullam ob id factum calumniam metuere debet, a także cesarza Galliena z 265 r.: C.9,16,3 Gallien. Si, ut adlegas, latrocinantem peremisti, dubium non est eum, qui inferendae caedis voluntate praecesserat, iure caesum videri.

${ }^{45}$ G. Diósdi, Vim vi repellere licet..., s. 193, termin milites tłumaczy, zapewne poprawnie, jako „dezerterzy”, na co wskazuje treść dwóch konstytucji z 403 r. w sprawie karania dezertujących żołnierzy wydanych przez cesarzy: Arkadiusza, Honoriusza i Teodozjusza (C.3,27,2; 12,45,2). Por. także komentarz do terminu milites vel privati z podaniem innych jeszcze źródeł: The Theodosian Code and Novels and the Sirmondian Constitutions. A translation with commentary, glossary and bibliography by Clyde Pharr, Princeton 1952, s. 236, przypis 5. 
w ten sposób powstanie szczególnego (śmiertelnego) zagrożenia sytuacją, w której istnieje wręcz konieczność podjęcia zdecydowanej obrony.

Dalej z uzasadnienia regulacji można wywnioskować, że napadnięci ludzie mają prawo do działań obronnych polegających na zabiciu napastników, bo w ten sposób wykonują za państwo rolę karcącą wobec ewidentnych przewinień, które z punktu widzenia prawa karnego zasługiwałyby na karę. Konstytucja wyraźnie mówi o „spóźnionym”, czyli nieefektywnym działaniu państwa i wymiaru sprawiedliwości, gdyby napastnik zdążył zabić (okraść) swą ofiarę nie podejmującą obrony. Wyrok skazujący, czy zasądzający, nawet jeśliby ex post zapadł wobec sprawcy bezprawia, byłby zaledwie „pomszczeniem” ofiary, nie zwracając jej życia. Dlatego lepiej jest by napadnięty sam się bronił (a dostaje do tej obrony prawo, właśnie z woli samego państwa). Podobny argument był głośno podnoszony w nowożytnej nauce przez Grocjusza i Pufendorfa, twórców szkoły prawa natury, którzy powoływali się na tzw. umowę polityczną, w której państwo zobowiązuje się do obrony obywateli przed bezprawnymi zamachami na ich dobra. Jeżeli państwo zawodzi w realizacji swego obowiązku, wtedy każdy napadnięty obywatel ma prawo „wyręczyć” państwo w jego ochronnej funkcji podejmując się obrony swych dóbr na własną rękę ${ }^{46}$.

\section{Bibliografia:}

\section{Źródła prawa}

\section{Źródła rzymskie}

Cic. pro Milone

3,9

Codex lustiniani

$3,27,1 \mathrm{pr}$.

$3,27,2$

$8,4,1$

$9,16,2$

$9,16,3$

Codex Theodosiani

$9,14,2$

$12,45,2$

${ }^{46}$ Tzw. „teoria wyręczenia” miała również w Polsce swoich przedstawicieli, m.in.. Stanisława Śliwińskiego, Arnolda Gubińskiego, Witolda Świdę, por. J. Warylewski, Prawo karne. Część ogólna, Warszawa 2005, s. 229. 


\section{Collatio legum Mosaicarum et Romanarum}

$7,2,1$

$7,3,2$

$7,3,3$

Lex duodecim tabularum

8,12-13

8,14

Digesta lustiniani

$1,1,3$

$4,2,0$

$4,2,13$

$9,2,0$

9, 2, 4 pr.

$9,2,4,1$

$9,2,45,4$

$43,16,1,27$

$43,17,1$ pr.

$48,7,7$

$48,8,9$

$50,17,176 \mathrm{pr}$.

Gai Institutiones

4,151-3

4,155

Pauli Sententiae

$5,23,29$

Źródła współczesne

art.423 kodeksu cywilnego

art. 25 §1 kodeksu karnego

\section{Literatura:}

Amielańczyk K., Vim vi repellere licet. Kilka uwag na temat genezy prawa do obrony koniecznej w prawie rzymskim, „Palestra” 11-12 (2008), s.109-119

Amielańczyk K., Czy kontratyp obrony koniecznej ma rzymską tradycję? W poszukiwaniu przesłanek dopuszczalności prawa do samoobrony w rzymskim prawie karnym, w: Quid leges sine moribus? Studia nad prawem rzymskim dedykowane Profesorowi Markowi Kuryłowiczowi w 65. Rocznicę urodzin oraz 40-lecie pracy naukowej (pod red. K. Amielańczyka), Lublin 2009, s. 51-72

Amielańczyk K., Vis - pomiędzy prawem rzymskich deliktów prywatnych a rzymskim prawem karnym publicznym, w: Przemoc w świecie starożytnym. Źródła, struktury, interpretacje, Lublin 2017, s. $283-298$

Bohácek M., Si se telo defendit, w: Studi in onore V. Arangio-Ruiz, I, Napoli 1953, s.147-172

Dajczak W., Giaro T., Longchamps de Beriér F. , Prawo rzymskie. U podstaw prawa prywatnego, Warszawa 2014 (2 wyd.) 
Dębiński A., Rzymskie prawo prywatne. Kompendium, Warszawa 2011

Digesta lustiniani, Digesta lustiniani. Digesta Jusyniańskie. Tekst i przekład, pod red. T. Palmirskiego, Kraków 2013-2017

Diósdi G., Vim vi repellere licet. A contribution to the study of the question of self-defence in Roman Law, "Acta Universitatis Wratislaviensis. Antiquitas", I (1963), s. 187-199.

Garofalo L., Pojęcia i żywotność rzymskiego prawa karnego, „Zeszyty Prawnicze UKSW“ 3.1 (2003), s. 7-41

Gintowt E., Rzymskie prawo prywatne w epoce postępowania legisakcyjnego, Warszawa 2005

Gioffredi C., I principi del diritto penale Romano, Torino 1970

Kaser M., Das Römische Privatrecht, II, München 1975

Kelly J.M., Roman Litigation, Oxford 1966

Kuryłowicz M., Ustawodawstwo rzymskie w sprawach karnych, „Annales UMCS” 35.1 (1988), s.29-30

Labruna L., Vim fieri veto. Alle radici di una ideologia, Napoli 1971

Lacché L., Latrocinium, Milano 1988

Litewski W., Rzymskie prawo prywatne, Warszawa 1999

Litewski W., Podstawowe wartości prawa rzymskiego, Kraków 2001

Litewski W., Rzymski proces karny, Kraków 2003

Longo G., Sulla legittima difesa e sullo stato di necessità in diritto romano, w: Sein und Werden im Recht. Festgabe für U. von Lübtow, Berlin 1970, s. 321-328

Lucernoni M.F.P., Gli stationarii il Età Imperiale, Rome 2001

Luzzato G., Von der Selbsthilfe zum römischen Prozeß, „Zeitschrift der Savigny - Stiftung für Rechtsgeschichte. Romanistische Abteilung" 73 (1956), s. 27-67

Łoposzko T., Zarys dziejów społecznych cesarstwa rzymskiego, Lublin 1989

Mayer-Maly T., Vis, „Paulys Realencyclopädie“ IX A (1961), s. 315-327

Mozgawa M., (red.), Prawo karne materialne. Część ogólna, Warszawa 2011

Robinson O., The Criminal Law of Ancient Rome, Baltimore 1996

Sondel J., Słownik łacińsko-polski dla prawników i historyków, Kraków 1997

Staszków M., Teoria o „Selbsthilfe” i jej „nowocześni” krytycy, „ZN UWr” 27, Prawo 7 (1960), 201-216

Tarwacka A., Searching for the Roots. Vis vi depulsa in the Concept of Cicero, "Miscellanea historico-iuridica", 11 (2012), s.77-88.

The Theodosian Code and Novels and the Sirmondian Constitutions. A translation with commentary, glossary and bibliography by Clyde Pharr, Princeton 1952

Waldstein W., rec. G. Longo, Sulla legittima difesa e sullo stato di necessità in diritto romano, w: Sein und Werden im Recht. Festgabe für U. von Lübtow, Berlin 1970), „Zeitschrift der Savigny

- Stiftung für Rechtsgeschichte. Romanistische Abteilung“ 89 (1972), s. 476- ????

Warylewski J., Prawo karne. Część ogólna, Warszawa 2005

Wenger L., Institutes of Roman Law of Civil Procedure, New York 1955

Wieacker F., Endoplorare. Diebstahlsverfolgung und Gerüft in altrömischen Recht, w: Festschrift für L.Wenger I, München 1944, s. 129-179

Wiliński A., Das römische Recht. Geschichte und Grundbegriff des Privatrechts mit einem Anhang über Strafrecht, Leipzig 1966

Wołodkiewicz W., Zabłocka M., Prawo rzymskie. Instytucje, Warszawa 2005

Zabłocka M., Quaestio cum lance et licio „IURA" 54 (2003), s. 109-121

Zabłocka M., Quaestio cum lance et licio, w: Contra leges et bonos mores. Przestępstwa obyczajowe w starożytnej Grecji i Rzymie (pod red. H. Kowalskiego i M. Kuryłowicza), Lublin 2005, s. 379-388

Zabłoccy M. i J., Ustawa XII Tablic. Tekst-tłumaczenie-objaśnienia, Warszawa 2000 


\section{Streszczenie}

Celem artykułu jest prezentacja rzymskich regulacji dotyczących samopomocy z perspektywy metod kwalifikacji jej dopuszczalności z uwzględnieniem zarówno normatywnej treści oryginalnych aktów prawnych (Ustawa XII Tablic, Ustawa Akwiljańska, prawo pretorskie), jak i treści dodanych przez cesarzy i jurysprudencję. Samopomoc stanowiła alternatywną drogę zapewnienia efektywnej ochrony praw prywatnych w prawie rzymskim począwszy od okresu archaicznego aż po czasy justyniańskie. Należy odróżnić samopomoc aktywną i samopomoc pasywną. Samopomoc aktywna była stale poddawana ograniczeniom, aż w końcu została zakazana dekretem Marka Aureliusza (decretum divi Marci). Jeśli chodzi o samopomoc pasywną, można stwierdzić, że obecność i znaczenie zasady vim vi repellere licet są oczywiste od narodzin rzymskiego prawa prywatnego. Rzymianie nie stworzyli żadnych teoretycznych podstaw dla samopomocy, w szczególności dla uprawnionego pozbawienia kogoś życia, jednakże pomimo braku odpowiednich teoretycznych konstrukcji dla samopomocy nie kwestionowali zasady, że „siłę można odeprzeć siłą”. W ten sposób, w warunkach „obrony koniecznej”, które to uprawnienie wynikało już z samego prawa natury, a następnie zostało potwierdzone w ustawach, dozwolone było nawet pozbawienie życia napastnika, który zagroził naruszeniem dóbr ofiary takich jak życie, zdrowie czy mienie.

Słowa kluczowe: samopomoc, obrona konieczna, vis, furtum manifestum, vim fieri veto, decretum divi Marci.

\section{Self-help as an alternative way to secure effective protection of private rights in Roman Law}

\section{Summary}

The article aims to present Roman regulations concerning self-help, from the perspective of the methods of classifying its legality taking into account both the normative contents of original laws (lex duodecim tabularum, lex Aquilia, ius praetorium), as well as those added by later legislative factors: emperors and jurisprudence. Self-help was an alternative way to secure effective protection of private rights in Roman law since archaic period to Justinian's time. The active self-help can be differentiated from the passive one. The active self-help have been constantly limited and finally was forbidden by decretum divi Marci. As to the passive self-help one may say, that the presence and meaning of vim vi repellere licet principle in the Roman private law was obvious from its very beginning. Romans did not come up with theory on the self-help, specially with theory of the justification of lawful killing. However, in spite of the absence of proper constructions of self defense in Roman private law, this is out of question that Romans could agree with the rule: "force can be repelled by force". In this way, under the right to "necessary self-defense" that already stemmed from the very law of nature, yet was confirmed in laws, it was even allowed to kill attacker who threatened to violate such interests of the victim as life, health or property.

Keywords: self-help, necessary self-defense, vis, furtum manifestum, vim fieri veto, decretum divi Marci. 